\title{
The rescue excavation project at the Neolithic settlement of Vasilika Kyparissi in central Macedonia, Greece
}

Maria Pappa ${ }^{1, *} \&$ Stratos Nanoglou ${ }^{2}$

Settlement in Neolithic South-eastern Europe has traditionally been divided into tell sites and flat sites. The results of rescue excavations at Kyparissi challenge a strict dichotomy.

Keywords: Greece, Neolithic, rescue archaeology

Discussions of how people lived in early agropastoral communities in South-eastern Europe (i.e. during the Neolithic, from the middle seventh to the late fourth millennia BC) have focused on the form of settlements. One particular form, the tell (magoula or toumba in Greece), has dominated the prehistoric archaeology of the region since the beginning of the twentieth century (Kotsakis 1999: 66). During the last three decades, however, it has been increasingly accepted that the tell was not the only settlement type in the area, and significant areas of flat extended settlements have been excavated (for examples in Greece, see Pappa 2008). Research into Neolithic communities has taken account of this divergence in settlement form, producing innovative results that build on comparisons between the two types (e.g. Bailey 1990; Chapman 1997; Hodder 1998; Kotsakis 1999; Tringham 2000; Nanoglou 2001; Pappa 2008). Important issues that have been highlighted are: intercommunity and intra-community spatial organisation; agricultural practices and animal husbandry; selective deposition of artefacts and organic material; and the commemoration of history in the past. The sustained flow of publications that focus on this binary settlement form (for several recent papers, see contributions in Sarris et al. 2017) reveals the importance that is placed on the issue, despite the call to consider the practices shaping these forms, rather than the forms themselves (Nanoglou 2008).

It is against this background that we present a preliminary view on the rescue excavation project at the Neolithic settlement at Vasilika Kyparissi, in central Macedonia, Greece. Post-excavation work is ongoing, but already the site offers an opportunity to refocus discussion because Kyparissi does not fit the 'tells vs flat settlements' model and demands a new approach (Nanoglou 2008).

The site is $20 \mathrm{~km}$ to the south-east of Thessaloniki, near the modern village of Vasilika; it is approximately $18 \mathrm{ha}$, based on data provided by the 'Anthemous Survey Project' that surveyed the wider area (Andreou et al. 2016). The main occupation of the site dates to the Middle and Late Neolithic periods (sixth to early fifth millennia BC); a small mound dated to the Early

\footnotetext{
1 Ephorate of Antiquities of the Thessaloniki Region, Marias Kallas 21A Street, Thessaloniki 54646, Greece

2 Ephorate of Antiquities of Pella, Archaeological Museum of Pella, Pella 58005, Greece

* Author for correspondence (Email: mpappa@culture.gr)
} 
Bronze Age (third millennium BC) has also been identified at the northern extent of the site. Construction works within the area of the settlement necessitated a rescue excavation, which was conducted from 2013-2015 (Pappa et al. 2017). The excavation, although limited in scale (approximately $3 \times 300 \mathrm{~m}$ ), revealed part of the settlement thereby enabling better understanding of its use (Figure 1).

The site is larger than most flat sites and yet the depth of debris amassed is considerablereaching nearly $6 \mathrm{~m}$ in places. This is sometimes thought to signify a large population (e.g. Grammenos 1997: 285-88), but we argue that it represents a combination of practices that the 'tells vs flat sites' model usually understands as mutually exclusive: the continuous rebuilding of structures at the same spot (recognised as a tell phenomenon); and a dispersed building arrangement, with relatively large open spaces between buildings (associated with flat sites). At Kyparissi, the horizontal expansion of the site coincides with the vertical superimposition of buildings. It is interesting that at Kyparissi the main building material is mud-brick (Figure 2); after the buildings have ceased to be used, the debris from their superstructure was deposited on the spot, raising the ground. This is rarely found in central Macedonia, where most Neolithic settlements are extended flat sites with structures built from daub on a wooden framework, whose debris is deposited in pits and ditches.

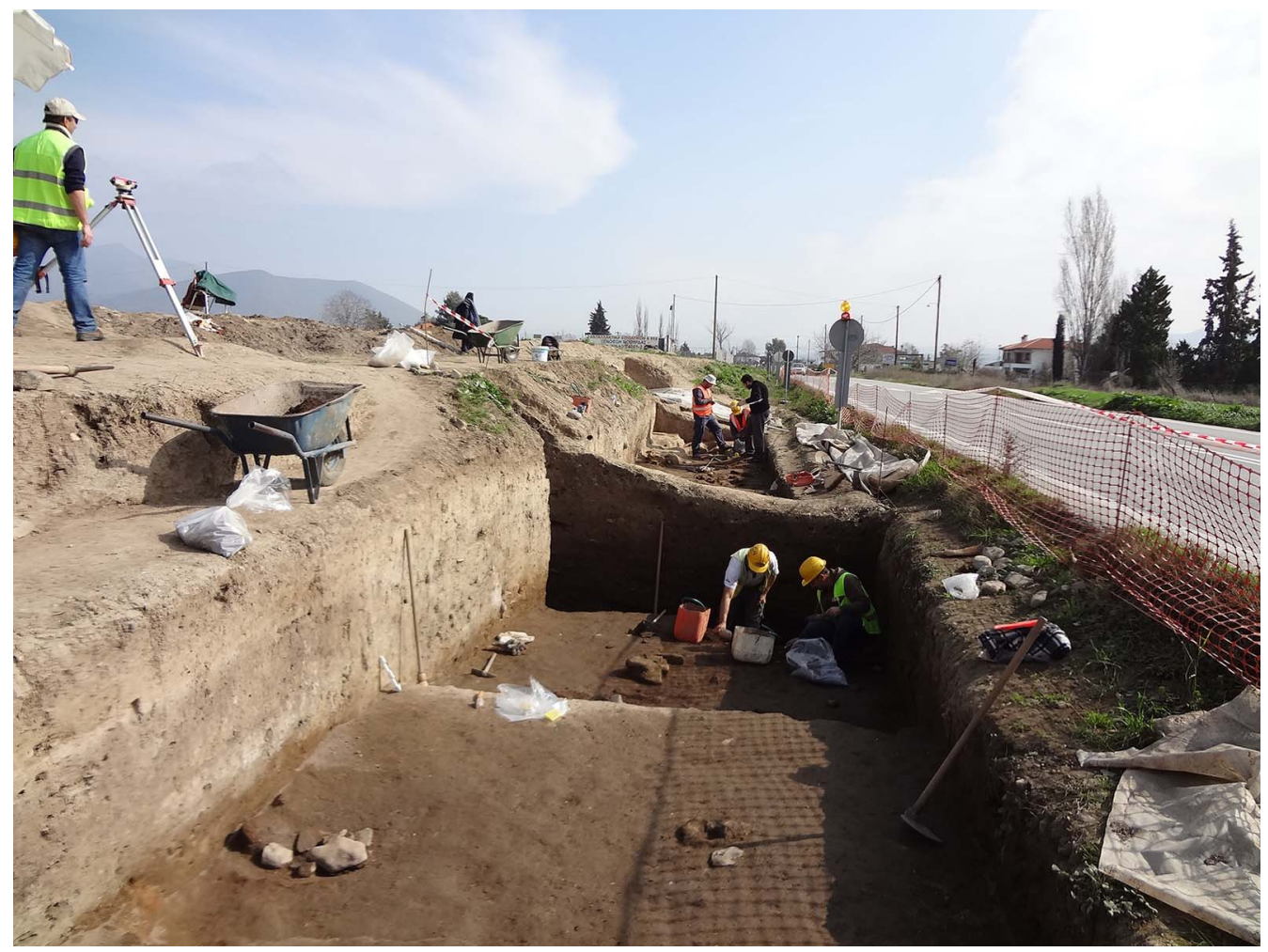

Figure 1. View of excavated area (credit: Ephorate of Antiquities of Thessaloniki Region).

(C) Antiquity Publications Ltd, 2019 

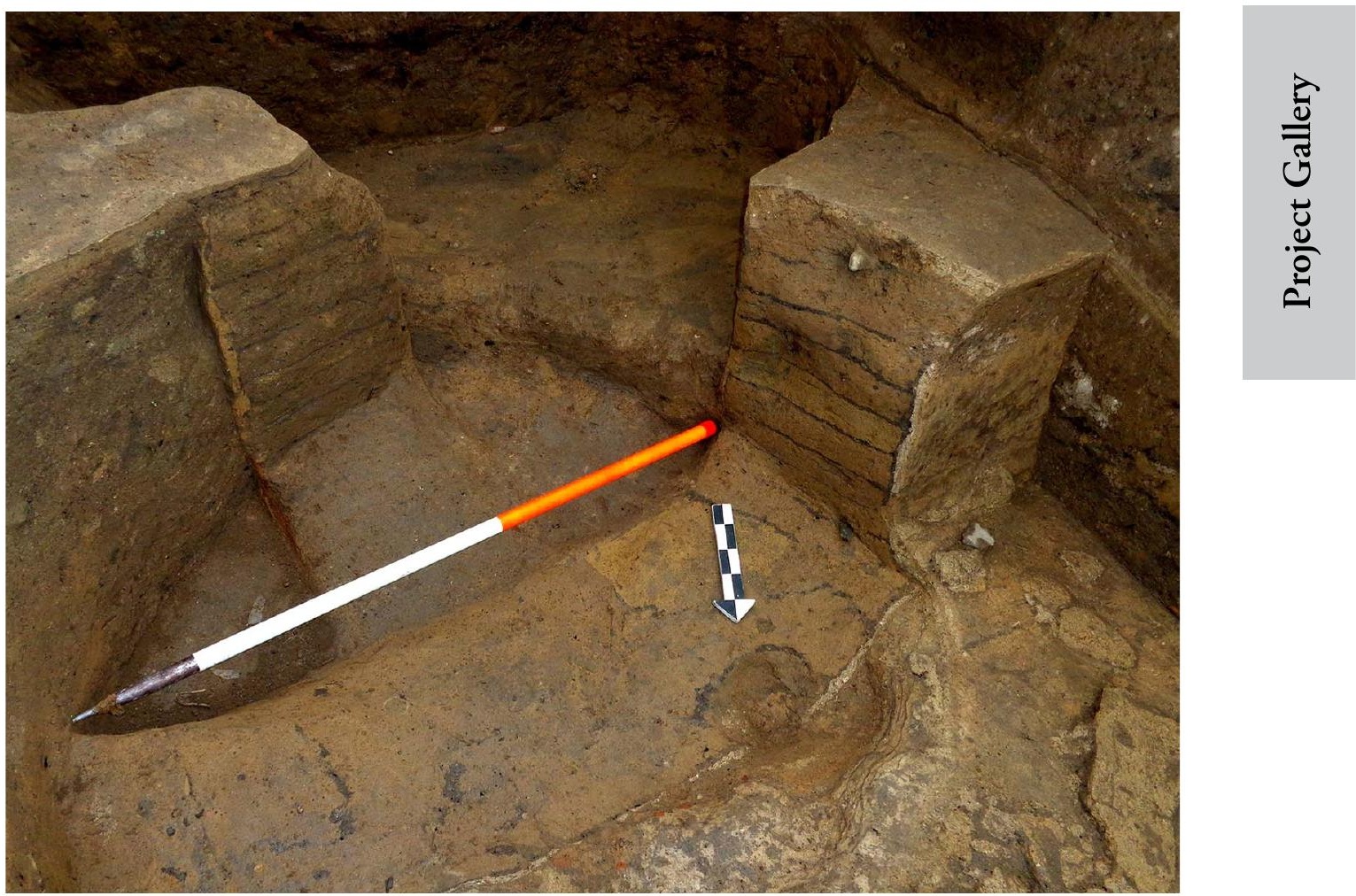

Figure 2. Mud-brick walls cut by a later pit (credit: Ephorate of Antiquities of Thessaloniki Region).

At Kyparissi, roofed structures interpreted as houses (Figure 3) are next to open areas, often equipped with fire installations, such as hearths and ovens (Figure 4). Among the houses are extended middens and refuse pits. Several pits, which do not seem to have been used for refuse or storage, cut layers of occupation debris and could suggest symbolic practices (Figure 3).

Finds from the site include pottery dating to the Middle and Late Neolithic (Figure 5), with some Final Neolithic sherds. The deposition of nearly complete vessels in certain contexts is significant in relation to the biography of these artefacts, but the pottery study also included technological and morpho-stylistic analysis of approximately 50000 sherds, which will provide a statistically sound basis for reconstructing their use at the site.

The finds assemblage includes most of the characteristic repertoire of the period; a large collection of stone artefacts, possibly for personal adornment, is notable however, as are the bone artefacts, including bone tools. The chipped stone tools and other worked stone differ from neighbouring sites, such as Thermi (Pappa 2007). The number of tools and quantity of debitage is very small compared to the assemblage from Thermi, which may be a manufacturing site. More than half of the lithic assemblage from Kyparissi is made of siliceous limonite and quartz, the rest is made from raw materials of varying quality and provenance. A remarkable find from a destruction level within the Late Neolithic houses suggests a network of exchange with northern areas; it is a large flint blade approximately $142 \times 50 \mathrm{~mm}$,

(C) Antiquity Publications Ltd, 2019 


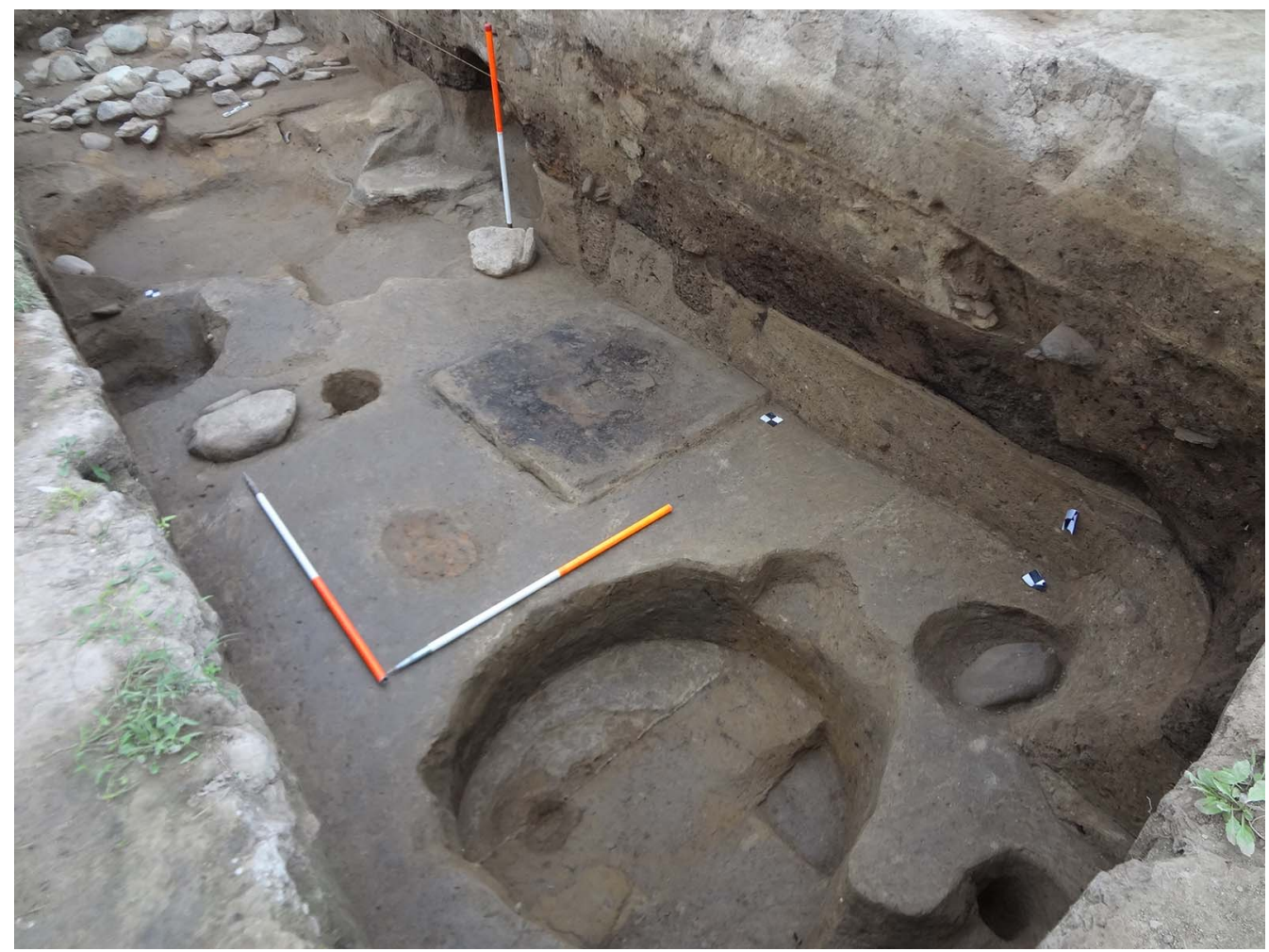

Figure 3. Successive occupation phases cut by later pits (credit: Ephorate of Antiquities of Thessaloniki Region).

approaching $190 \mathrm{~mm}$ in length, including broken pieces. The raw material is not local, and a blade of this size has never been reported from Greece (Figure 6).

Several pots discovered in situ with a thick layer of burnt seeds and fruits, including many figs, were preserved in the same context. This find is not uncommon, but it is one of the earliest in Greece, as pottery securely dates the context to the earliest phase of the Late Neolithic period. A wide range of cereals and pulses have been identified within 130 samples retrieved from the site. Einkorn (Triticum monococcum), emmer (Triticum dicoccum) and a new glume wheat type (Triticum cf. timopheevi) are present both as grain and chaff. Cracked barley (Hordeum vulgare) was also found in large quantities, suggesting a form of processing that is currently under investigation. Lentils (Lens sp.), bitter vetch (Vicia ervilia), grass pea (Lathyrus sativus) and probably pea (Pisum sp.) are present in samples from the site. Fruits include grape (Vitis vinifera), blackberry (Rubus fruticosus agg.) and fig (Ficus carica).

The faunal assemblage from Kyparissi is dominated by domestic species. Ovicaprids (Ovis aries and Capra hircus) outnumber all the other domesticates; there was some pig (Sus domesticus), fewer cattle (Bos taurus) and still fewer dogs (Canis familiaris) present. Wild taxa appear in significantly lower numbers.

There are intriguing differences between the finds assemblage from Kyparissi and those from contemporaneous sites. The most significant aspect of this site, however, is that it offers an opportunity to study the varied lifestyles that produced a settlement form that defies (C) Antiquity Publications Ltd, 2019 


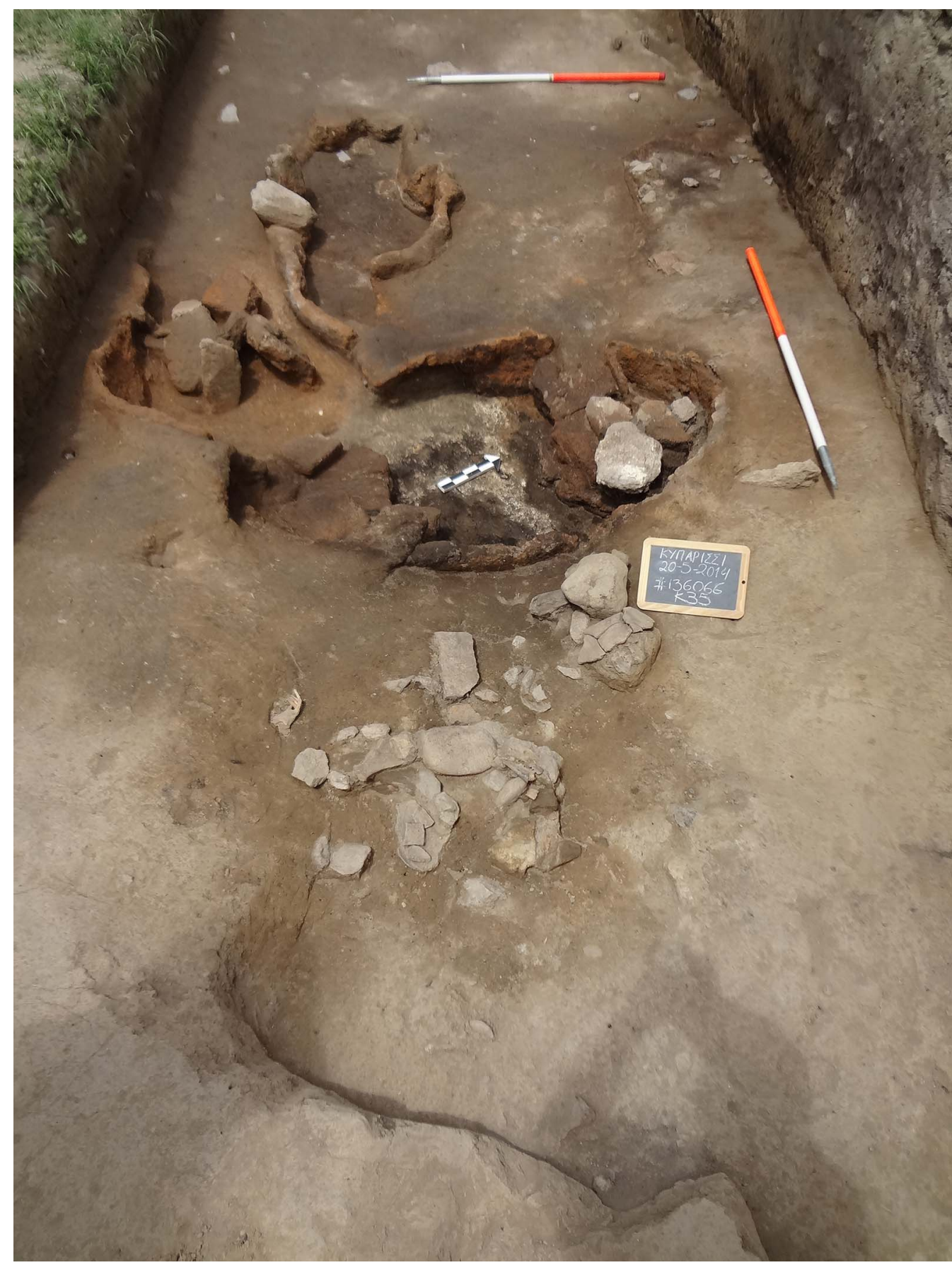

ป

Figure 4. Open areas provided with fire installations (credit: Ephorate of Antiquities of Thessaloniki Region). 

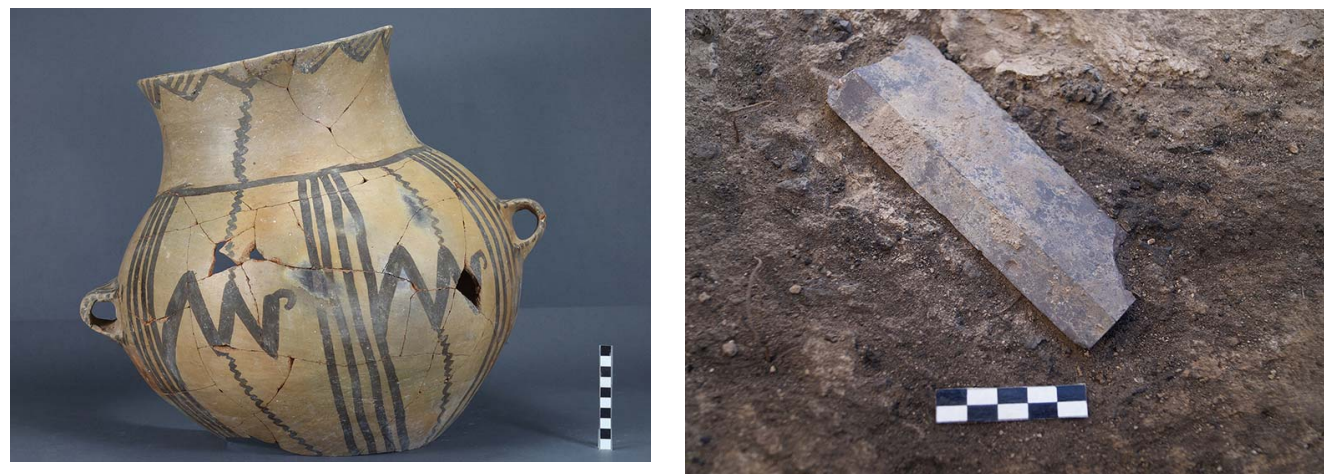

Figure 5. Large closed pot with painted decoration in a Figure 6. Flint blade (scale in centimetres) (credit: matt finish (scale in centimetres) (credit: Ephorate of Ephorate of Antiquities of Thessaloniki Region).

Antiquities of Thessaloniki Region).

established types. Our ongoing study of Kyparissi strongly suggests that people employed a variety of strategies with divergent outcomes, demonstrating that life in the South-eastern European Neolithic should not be dichotomised.

\section{Acknowledgements}

The project has been funded by INSTAP since 2017. The present report was made possible by contributions from: M. Efthymiadou; S. Kyrillidou (micromorphology); P. Lathiras and S.M. Valamoti (plant remains); J. Gibajas and N. Mazzucco (lithics); J. Kozatsas and K. Kotsakis (pottery); D. Kadi, S. Triantafyllou and P. Halstead (animal and human bones).

\section{References}

Andreou, S., J. Czebreszuk \& M. Pappa (ed.). 2016. The Anthemous Valley Archaeological Project. A preliminary report. Poznań: Wydawnictwo Naukowe UAM.

BAILEY, D. 1990. The living house: signifying continuity, in R. Samson (ed.) The social archaeology of houses: 19-48. Edinburgh: Edinburgh University Press.

Chapman, J. 1997. The origins of tells in eastern Hungary, in P. Toping (ed.) Neolithic landscapes (Neolithic Studies Group Seminar Papers 2): 139-64. Oxford: Oxbow.

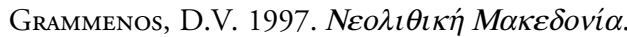
Athens: Archaeological Receipts Fund.

Hodder, I. 1998. The domus: some problems reconsidered, in M. Edmonds \& C. Richards (ed.) Understanding the Neolithic of North-western Europe: 84-101. Glasgow: Cruithne.

KotsaKis, K. 1999. What tells can tell: social space and settlement in the Greek Neolithic, in P. Halstead (ed.) Neolithic society in Greece: 66-76. Sheffield: Sheffield Academic.

(C) Antiquity Publications Ltd, 2019
NANOGLou, S. 2001. Social and monumental space in Neolithic Thessaly, Greece. European Journal of Archaeology 4: 303-22. https://doi.org/10.1179/eja.2001.4.3.303

- 2008. Building biographies and households: aspects of community life in Neolithic northern Greece. Journal of Social Archaeology 8: 139-60. https://doi.org/10.1177/1469605307086081

PAPPA, M. 2007. Neolithic societies: recent evidence from northern Greece, in H. Todorova, M. Steganovic \& G. Ivanov (ed.) The Strumal Strymon River valley in prehistory: 257-72. Sofia: Gerda Henkel Stiftung.

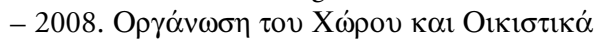

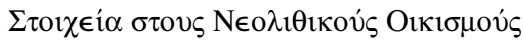

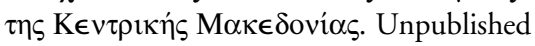
$\mathrm{PhD}$ dissertation, Aristotle University of Thessaloniki.

Pappa, M., S. Nanoglou \& M. Efthymiadou. 2017. A road to variation: divergence among Neolithic settlements in central Macedonia, Greece, in A. Sarris, E. Kalogiropoulou, T. Kalayci \& E. Karimali (ed.) Communities, 
The rescue excavation project at the Neolithic settlement of Vasilika Kyparissi in central Macedonia, Greece

landscapes and interaction in Neolithic Greece: 49-59. New York: Berghahn.

Sarris, A., E. Kalogiropoulou, T. Kalayci \& E. Karimali (ed.). 2017. Communities, landscapes and interaction in Neolithic Greece. New York: Berghahn.
Tringham, R. 2000. The continuous house, in R.A. Joyce \& S.D. Gillespie (ed.) Beyond kinship: social and material reproduction in house societies: 115-34. Philadelphia: Pennsylvania State University Press.

Received: 6 February 2019; Revised: 2 May 2019; Accepted: 18 March 2019 